\title{
School Based Mental Health: A School Counselor's Reflection
}

\author{
Dr. Jill M. Thompson \\ Associate Professor, Counseling \\ Prairie View A \& M University \\ United States
}

\begin{abstract}
The case studies presented in this article were produced by counselors-in-training in a master's degree program at a southeastern university. The purpose of this manuscript is to present case studies pertaining to areas of concern that have been recognized from the perspective of counselors in training participating in $P-12$ internships within the inner city and urban school systems.
\end{abstract}

The practice of reflection has been identified as an important component of counselor development (Neufeldt, Karno, \& Nelson, 1996). For this article, the authors defined reflective thinking as the active, ongoing examination of theories, beliefs, and assumptions that contribute to school counselor interns' understanding of P12 student issues, and guide their choices for strategies and interventions. The competency of school counselors is measured by their abilities to understand and conceptualize complex problems (Brown and Trusty, 2005). Therefore, the development of reflective thinking is an important objective of counselor education programs. The reflective technique of case study introspection is encouraged; because the process is useful for encouraging $\mathrm{P}-12$ students to think critically about assumptions that guide the counseling practice and include opportunities for feedback (King \& Kitchener, 1994). Based on observations as a counselor educator, using case studies has been an effective teaching strategy to increase critical thinking. The focus of this article involves the social-emotional issues that P-12 students experience that school counselor's face in urban school environments.

Case studies are used in education to further assist students to reflect on the cultural environment they work within. The case study technique is applied in a variety of instructional situations. To provide the most complete understanding possible, case studies are used typically to examine the relationships of all variables. Case studies involve a type of comprehensive understanding determined by a process known as thick description. The comprehensive understanding involves in-depth descriptions of the entities being evaluation, the circumstances, the characteristics of the people involved, and the nature of the community. Additionally, thick descriptions involve interpreting the meaning of demographic and descriptive data, such as cultural norms and mores, community values, ingrained attitudes, and motives.

Case study refers to the collection and presentation of detailed information about a particular participant or small group, which frequently includes the accounts of the participants. As a form of qualitative descriptive research design, the case study methodology is used to examine intensely at an individual or small participant pool, allowing the researchers to develop conclusions about that participant or group within the specific context only (Yin, R. 1994). Using reflection, practitioners can expose and criticize the tacit understandings resulting from the repetitive experience of a specialized practice and make new sense of the uncertain or unique situations they have experienced (Schon, 1991). Officials at the American School Counseling Association (2008) identified counselors as uniquely qualified to address all students' academic, personal/social, and career developmental needs. Further, counselors play an essential role in maximizing student success (American School Counseling Association, 2008).

\section{Elementary School Counselors}

Elementary school years set the foundation for children to develop the knowledge, attitudes, and skills necessary to become healthy, competent, and confident learners (Henderson \& Thompson, 2011; Sink, 2005). In a comprehensive developmental school-counseling program, the school counselor teams with school staff, parents, and community members to create a caring climate and atmosphere for children. 
By providing education, early identification of conduct disorders, and intervention for inappropriate conduct, school counselors can help every child achieve academic success. Professional elementary school counselors must hold a master's degree and maintain required state certification in school counseling ( Dollarhide \& Saginak, 2017). Maintaining certification involves on-going professional development to remain knowledgeable on issues of education reform and the challenges facing students (Brown \& Trusty, 2005) in modern schools. Membership with pertinent professional associations is useful for enhancing a school counselor's knowledge and effectiveness.

\section{Middle School Counselors}

Middle school students are characterized by rapid physical growth, curiosity about their world, and emerging selfidentity issues (Henderson \& Thompson, 2011; Boyd \& Bee, 2015). Middle school counselors enhance the learning process and promote academic achievement.

School-counseling programs are essential and used to help students achieve optimal personal growth, acquire positive social skills and values, set appropriate career goals, and realize their full academic potential to become productive, contributing members of their communities A professional middle school counselor needs to hold a master's degree and maintain required state certifications in school counseling. Maintaining certifications, including on-going professional development, assures counselors remain abreast of education reform issues, and current challenges facing students. Membership in a professional association is encouraged, because it is useful for enhancing the school counselor's knowledge and effectiveness.

\section{High School Counselors}

For students, the high school years are filled with growth, promise, excitement, frustration, disappointment, and hope. It is the time when students begin to discover what the future holds for them. For students, secondary school counselors enhance the learning process and promote academic achievement (Henderson \& Thompson, 2011; Boyd \& Bee, 2015). School counseling programs are essential for helping students achieve optimal personal growth, acquiring positive social skills and values, setting appropriate career goals, and realizing their full academic potential as productive, contributing members of their communities. Professional high school counselors hold a master's degree and maintain required state certifications in school counseling (Schmidt, 2014). Regardless of their level, professional school counselors are certified/licensed educators who are qualified to address the developmental needs of all students using the implementation of a comprehensive school counseling program, which is results-based and data-driven (American School Counseling Association, 2008). For school counselors, the most important aspect in building, maintaining, implementing, and evaluating programs is data (Sink et.al, 2008). The goal for school counselors is student success; therefore, the implementation of effective interventions produces the best outcomes (Schmidt, 2014). To accurately identify the needs of the school population, data collection is necessary (American School Counseling Association, 2004). Case studies are used as an effective source of data, because frequently they are discussed within the context of qualitative research and naturalistic inquiry.

Often, the term, case study, is used interchangeably with ethnography, field study, and participant observation (William, 2007). The underlying philosophical assumptions in case studies are similar to these types of qualitative research (ethnography, field study, participant observation), because all occur in a natural setting, such as a classroom, neighborhood, or private home. Case study is not a new form of research, because naturalistic inquiry was the primary research tool used until the scientific method was developed (Colorado State University, 1993-2010).

Case study is an in-depth exploration of a particular context or population, such as a classroom or group of individuals, and involves the collection of extensive qualitative data usually through interview, observation, and document analysis (State Educational Technology Directors Association, 2008). Typically, counseling case studies include the demographics of students, reasons for referral, sequences of events, fictitious names, and any other pertinent information regarding the students referred for counseling. Normally, case studies are used to examine the interplay of all variables to provide a complete understanding of an event or situation (Colorado State University, 1993-2010). The use of the case study as an instructional delivery method transfers much of the responsibility for learning from the instructor to the student who, as a result, shifts away from passive absorption to active construction (Boehrer \& Linsky, 1990). Using careful examination and discussion of various cases, counselors-in-training learn to identify actual problems, recognize all contributing factors, and increase awareness of the student's key experience (Merseth, 1991). 
Therefore, when presented with a case, the counselor-in-training can effectively conceptualize and approach the case using assessments, intervention procedures, then apply theories to generate effective and appropriate strategies and interventions (Studer, 2005). Implementing case studies into the counselor training environment is beneficial for counselors-in-training when assessing the application of concepts to complex real world situations, and the application of theories to generate effective and appropriate strategies and interventions (Dunn and Brooks, 2004). Working in groups on case studies can also help counseling-in-training students develop interpersonal skills and their abilities to work in teams (Center for Teaching and Learning, 1994). Case studies are useful in helping students make connections between obvious issues and deeper issues of concern (Center for Teaching and Learning, 1994).

In the training environment, case studies are used to synthesize real life scenarios for counselors-in-training. Case studies are used to help counselors-in-training gain insight into creating and building strategies and interventions via group discussions (McLeod, 2010).

Case studies are used to require the counselor-in-training to isolate and contemplate the essential issues compared to theoretical concepts and the impact of the larger environment (Peters, 2000-2006). Additionally, case studies are useful for preparing counselors-in-training to build on their knowledge and skills, using their invaluable experiences within the field and the classroom, to present a best solution rationale, and make recommendations as a team for each case. Working among colleagues to problem solve on abstract ideas is the essence of personal empowerment and the efficacy of counselors-in-training (Shulman, 2004). Counselor educators use case studies to build a repertoire of methods and solutions that are useful when they enter the school environment. In the training environment, case studies are used to brainstorm ideas, encourage dialogue, and produce action plans (McLeod, 2010). Gaining the concept of teamwork, counselors-in-training expand on their level of perception by being able to gain a wider scope of society (Peters, 2000-2006).

Provided in the current document are P-12 case studies that highlight identified needs and interventions from the perspectives of counseling interns enrolled in a master's degree program. Sharing information from the field increases the repertoire of strategies and interventions for future clients and cases. The cases presented are authentic P-12 cases that interns encountered during their field experience.

\section{P-12 Social-Emotional Case Studies}

\section{Elementary School Level}

\section{Case Study One:}

Demographics. An 8-year-old third grader. She is Dominican and attends an inner city school in a southwestern metropolitan city. She is an only child and lives with her mother and grandmother. Her grandmother acts as her primary caregiver, because her mother has two jobs. However, her mother drops her off at school in the mornings, and then goes to work. Her father separated from the family in 2009.

Background information. She attended a different school for second grade. Her mother reported when she began the second grade she struggled with separating from her mother when arriving at school. After three months, Raiza adjusted to the separation from her mother at school in the mornings. Currently, Raiza is in a new school and she is displaying the same separation behaviors. Specifically, when Raiza walks into the school building, she begins crying hysterically, complaining of stomachaches and, occasionally, she regurgitates. The initial response by the administrator regarding Raiza's behavior was to dismiss her from school, but when the daily pattern was noted, the counselor suggested that the mother take Raiza to the pediatrician. The mother returned and told the counselor that she had taken Raiza to the hospital and the doctor found that she had a mild urinary tract infection (UTI).

Reason for referral. Raiza was referred to the school counselor because of her struggle to separate from her mother. Raiza has emotional outbursts when her mother leaves her at school. The school counselor was asked to assist with Raiza in the mornings when she was dropped off at school based on her consistent crying and complaining.

Sequence of events. The day after Raiza was seen by her pediatrician, she came to school and began crying and begging her mother not to leave. Raiza said she did not want to stay at school and complained she did not feel well. 
The counselor pulled Raiza aside and said, If you calm down, your mother will stay out here in the hallway for a while until you get settled and then leave. But, if you continue to cry she is going to leave and you will have to stay here anyway. As a result, Raiza calmed down and her mother departed. Immediately, Raiza began to cry and beg for her mother. One of the teachers who was in the hallway attempted to calm her down, asking Raiza to join her in her classroom. Raiza went with the other teacher and appeared to regain her composure. While in the classroom, the teacher asked Raiza if she wanted to talk about how she was feeling. Raiza responded "No", but she was willing to write how she felt. Raiza wrote, "I don't like when my mother leaves, because I am scared she won't come back. I know my mom gets mad when I cry but I can't help it." The situation with Raiza has been ongoing since the school year began. Though her emotional displays vacillated from mild to extreme, the counselor noticed that it was worse after weekends.

Fresh eyes: Strategies and interventions. Raiza verbalized that she does not like it when her mother leaves her, because she is scared that her mother will not return. Therefore, helping Raiza understand patterns of consistency regarding her mother returning daily to get her from school may help Raiza adjust more easily when coming to school in the morning.

Strategy 1. The first strategy can be to place a picture of her mother on the front side of an index card and on the back side list the drop off times in the morning, lunch time, and the pick-up time. The lunch time can be explained to Raiza as the halfway point in the day to seeing her mother again. The index card would be placed on Raiza's desk with a clock pointing out the times for each milestone. The purpose of the card would be shared with Raiza, explaining to her that if at any time during the school day she feels scared or misses her mother, that she can flip the card over and see the picture of her mother.

Strategy 2. Strategy 2 involves inviting Raiza's mother to the school to have breakfast with Raiza. The rationale is the strategy would provide a sense of security for Raiza and be useful in allowing her to become comfortable in the school environment before her mother leaves.

\section{Case Study Two: Evan}

Demographics. Evan is a 6-year-old kindergartner. He is African American and attends school at an inner city southeastern public school. Evan lives with his biological mother, a stepfather, and two biological sisters, who are 12 and 16 years old, respectively. Evan is the youngest. At the age of three, Evan was hit by a car and was medically evaluated. Currently, Evan has not incurred any major problems from the accident and has not had any medical follow-up since the accident.

Background information. Academically, Evan is on target for his age and grade level. Evan was discharged from his previous school, because his residence was outside of that school's zone. Evan has been at his current school for six weeks. Within the short 6-week tenure at his current school, Evan has been suspended twice and referred to the counselor's office three times for inappropriate behavior in the classroom, such as screaming, yelling, and throwing his body on to the ground while crying. As affirmed by the counselor-in-training and observations and communications from his teacher, usually the episodes occurred when Evan was asked to complete a task that he did not want to complete. The 4-month period of anecdotal notes from Evan's teacher at his previous school highlighted incidents of Evan hitting other children and teachers, and inappropriate yelling and screaming, which are behaviors that he displays at his current school. Based on the duration and intensity of Evan's inappropriate behaviors, Evan was referred to the Student Support Team (SST) and the school's behavior specialist.

Reason for referral. Evan was referred to the school counselor for continuous inappropriate behavior in the classroom and in the school environment. Specific behaviors displayed were screaming, yelling, running, and jumping up and down in the classroom during instructional time. However, in a one-on-one setting Evan worked consistently, but struggled in a group setting. Currently, Evan has been referred to the SST and the school behavioral specialist.

Sequence of events. During the initial session with the counselor-in-training, Evan appeared to be energetic and friendly. He enjoyed playing computer games and drawing. Evan exhibited great imagination through drawing pictures. From a classroom observation, the counselor-in-training noticed that Evan enjoyed participating in class, but became distracted and off task. Evan's strength is his ability to work well with manipulatives with little assistance. However, Evan seeks constant praise. Furthermore, he cries, screams, and yells when he does not receive what he wants. 


\section{Fresh eyes: Strategies and Interventions}

Strategy 1. Evan will be asked to participate in individual counseling sessions on a weekly basis for a minimum of 30 minutes for 6 weeks. During the sessions, the counselor will focus on teaching Evan to learn self-control. Also, the counselor can implement a behavior chart showing appropriate and inappropriate behaviors, which are acceptable in the school environment. During the counseling session, the counselor will discuss the function of the chart and outline rewards for appropriate behavior with Evan. A meeting with parents to confer on the techniques to assist Evan in the home environment and a list of community agencies for additional assistance would be suggested.

Strategy 2. Evan would be engaged in small group settings to build his social skills and to help him work on making friends effectively. The counselor can observe the student-teacher interactions in the classroom to gain an understanding of areas that can be modified and adjusted. The counselor would provide constructive feedback for Evan's teacher.

The counselor can facilitate a consultation relationship among the counseling intern, teacher, and Evan to work on building a more structured environment and concrete rules (structure, boundaries, rules, and regulations) for Evan to follow. The strategy would be used to create a less stressful environment for the teacher and a safe and welcoming environment for Evan.

\section{Conclusion}

In this article, "thick description" and its relationship to a reflective case study method is discussed. The study has several potential implications for research, presentations, and treatment of behavioral disorders that educators face daily within the school environment. Most importantly, the main purpose of the article was to investigate reflective practice when working with elementary, and middle school students.

\section{References}

Adcock, S. S. \& Tucker, C. ( 2016). Counseling Children and Adolescents Connecting Theory, Development and Diversity. SAGE: Publications.

American School Counseling Association, (2008). Retrieved on April 11, 2012 from database: http://www.school counselor.org/content.asp

Boehrer, J. \& Linsky, M. (1990). Teaching with cases: Learning to question. New Directions for Teaching and Learning, 1990(42), 41-57. doi:10.1002/t1.37219904206

Bonwell, C. C. \& Eison J. A. (1991). Active Learning: Creating Excitement in the Classroom, ASHE-ERIC Higher Education Report No. 1. The George Washington University, School of Education and Human Development, Washington, DC.

Boyd, D. \& Bee, H. (2015). Lifespan Development, Boston, MA: pearson Education, Inc $7^{\text {th }}$ edition.

Brown, D. \& Trusty, J. (2005). Designing and learning comprehensive school counseling programs. Belmont, CA: Thomson Brooks/Cole

Center for Teaching and Learning. (1994). Speaking of teaching. Stanford University Newsletter on Teaching, 5(2). Retrieved April 12, 2010, from, http://ctl.stanford.edu/Newsletter/case_studies.pdf

Colorado State University. (1993-2010). Case studies. Retrieved April 11, 2010, from, http://writing.colostate. edu/guides/research/case study/com2a1.cfm

Cowen, J. (1998). On becoming an innovative university teacher: Reflection in action. Philadelphia, PA: Society for Research in Higher Education and Open University Press.

Dahir, C. A. \& Stone, B. C. (2012). The Transformed School Counselor, $2^{\text {nd }}$ Edition. Cengage Learning.

Dollarhide, C. T. \& Saginak, K. A. (2016). Comprehensive School Counseling Programs K-12 Delivery System in Action. Education , Boston.

Dunne, D. and Brooks, K. (2004). Teaching with Cases, Society for Teaching and Learning in Higher Education. Green Guide No.5 Dalhousie University, Halifax, Nova Scotia.

Ellis, A. K. (2001). Teaching, learning, and assessment together: The reflective classroom. Larchmont, NY: Eye on Education.

Erford, B. (20150. Transforming the School Counseling Profession. Pearson Education, Boston.

Henderson, D. A. \& Thompson, C. L. 920110. Counseling Children $8^{\text {th }}$ Edition, Cengage Learning. 
King, p. M. \& Kitchener, K. S. (1994). Developing reflective judgement: Understanding and promoting intellectual growth and critical thinking in adolescents and adults. San Francisco: Jossey-Bass.

McLeod, J. )2010). Case Study research in Counselling and Psychotherapy. Sage Publications.

Merseth, K. K. (1991, January). The case for cases in teacher education. Retrieved from ERIC database. (ED329541)

Parsons, R. D. (2007). Counseling Strategies that Work. Pearson Education, Boston.Peters, K., (2000-2006). Using cases in teaching. Penn State University. University Park, PA. Retrieved April 12, 2010, from http://tlt.its.psu.edu/suggestions/cases

Reed, A. J. S. \& Bergemann, V. E. (2001). Guide to observation, participation, and reflection in the classroom (4th ed.). New York, NY: McGraw-Hill.

Rhoads, R. A. \& Howard, J. P. F. (1998). Academic service learning: A pedagogy of action and reflection. San Francisco, CA: Jossey-Bass.

Sabella, R. A. (2004). Having the best information. Retrieved on April 14, 2010, from http://www.schoolcounselor.org/content.asp

Schmidt, J. J. (20140. Counseling in Schools: Comprehensive Programs to Responsive Services for All Students, $6^{\text {th }}$ Edition.

Schon, D. A. (1991). The Reflective Turn: Case Studies In and On Educational Practice. New York:Teachers Press, Columbia University.

Shulman, L. (2004). Professing the Liberal Arts. Teaching as community property: Essays on Higher Education, $1^{\text {st }}$ Edition. The Carnegie Foundation for the Advancement of Teaching, Jossey-Bass, CA. pp:26.

Sink, C. (2012). Mental Health Interventions for School Counselors, $1^{\text {st }}$ Edition.

State Educational Technology Directors Association. (2008). Definition of case study. Retrieved April 11, 2012, from http://www.setada.org/web/guest/glossary

Studer, J. R. (2005, April 1). Supervising school counselors-in-training: A guide for field supervisors. The Free Library. Retrieved April 11, 2010, from http://www.thefreelibrary.com/Supervising school counselors-intraining: a guideforfield-a0132229088

William, E. (2007). The Case Study Handbook, Harvard Business Review Press.

Yin, R. (1994). Case study research: Design and methods, $2^{\text {nd }}$ Edition. Thousand Oaks, CA: Sage Publishing. 